\title{
Analisis Pengaruh Konflik Peran Ganda dan Stres Kerja terhadap Kinerja Karyawan Wanita Menikah (Studi pada PT. Sukorintex Batang)
}

\author{
Rokhayatul Karomah \\ Program studi Manajemen, Fakultas Ekonomi, Universitas Wahid Hasyim Semarang \\ Email: rokhayatul@gmail.com
}

\begin{abstract}
Multiple conflict is a situation where is a sonflict betwen work assigments and tasks in the family that both demand priority. While work stress is a feeling that ia pressing or feeling depressed experienced by employees in the face of their work. This study aims to analyze the influence of multiple role conflict and work stress on the performance of married female employees at PT. Sukorintex Batang. In this study the data used are primary data and secondary data. The population in this study were married female employees in thedivision Packaging, amounting to 128 respondents. While the method used in sampling is probability sampling, which consists of sensor parts and cutter parts with a total of 90 respondents. The results of the t test (partial) in this study show that $t$ count 9.259> t table 1.98 or $p<0.05$, which means multiple role conflict has a positive and significant influence on the performance of married female employees, which is inversely proportional to the results of Endang Rusmawati's research and Ostevi.AJ namely multiple role conflict has a negative effect on the performance of female nurses in hospitals. Bethesda Yogyakarta, and work stress variables in this study obtained t count $(-0.015)<t$ table 1.98 or $p>0.05$ which means that work stress does not affect the performance of married female employees, where this is not in line with the Suci Larasati research .M, et al who have the results of work stress studies have a positive effect on the performance of female employees at PT. Pos Indonesia (Persero) Bandung in the sub division of the directorate of human resources.
\end{abstract}

Keywords: Dual ole conflict, Job stress, Employee performance women

\begin{abstract}
Abstrak
Konflik peran ganda merupakan suatu keadaan dimana adanya pertentangan antara tugas pekerjaan dan juga tugas di dalam keluarga yang sama-sama menuntut untuk diutamakan. Sedangkan stres kerja merupakan suatu kondisi yang mengakibatkan adanya rasa tertekan, tidak nyaman atau bahkan sakit pada seorang karyawan yang ditimbulkan dari lingkungan kerja atau kondisi pekerjaan yang dirasa dapat mengganggu kinerja dari seorang karyawan. Penelitian ini bertujuan untuk menganalisis pengaruh konflik peran ganda dan stres kerja terhadap kinerja karyawan wanita menikah pada PT. Sukorintex Batang. Dalam penelitian ini data yang digunakan adalah data primer atau kuesioner dan data sekunder atau wawancara. Populasi dalam penelitian ini adalah karyawan wanita menikah pada bagian Packaging. Sedangkan metode yang digunakan dalam pengambilan sempel adalah probability sampling, dengan jumlah sebanyak 90 responden. Metode analisis data yang digunakan adalah uji validitas, uji reliabilitas, uji asumsi klasik (uju normalitas, uji multikolonieritas, uji heteroskedastisitas), analisis regresi linier, uji regresi linier berganda, uju $t$ (parsial), uji F (simultan), dan uji koefisien determinasi. Pengujian secara parsial (uji t) variabel konflik peran ganda menunjukkan thitung 9,259>t tabel 1,98 dan taraf signifikansi $0,000<0,05$ sehingga terdapat pengaruh positif signifikan konflik peran ganda terhadap kinerja karyawan wanita menikah, pengujian secara parsial (uji t) variabel stres kerja menunjukkan t hutung $(-0,015)<t$ tabel 1,98, dan taraf signifikansi 0,988 > 0,05 sehingga tidak terdapat pengaruh stres kerja terhadap kinerja karyawan. Pengujian secara simultan (uji F) menunjukkan konflik peran ganda dan stres kerja berpengaruh dan signifikan terhadap kinerja karyawan wanita menikah. Hasil uji koefisien determinasi menunjukan pengaruh konflik peran ganda dan stres kerja terhadap kinerja karyawan wawnita menikah sebesar 70,7\% sedangkan 29,3\% lainnya dipengaruhi oleh model diluar variabel yang dibahas dalam penelitian ini.
\end{abstract}

Kata Kunci: Konflik peran ganda, Stres kerja, Kinerja karyawan wanita 


\section{PENDAHULUAN}

Wanita merupakan salah satu agen perubahan bangsa, dimana saat ini wanita memiliki peran penting dalam berbagai hal termasuk dalam proses pembangunan ekonomi negeri, sejak munculnya RA. Kartini yang memperjuangkan wanita untuk memiliki hak yang sama dengan laki-laki atau yang sering disebut dengan emansipasi wanita, kini wanita dan laki-laki memiliki porsi yang sama dalam pembangunan suatu negara, apalagi dalam proses pembangunan ekonomi, tidak dapat dipungkiri bahwa wanita adalah agent of development yang perannya sangat dibutuhkan dalam perkembangan ekonomi. Peran wanita dalam pembangunan ekonomi ini dapat dilihat dari angkatan kerja wanita, yang mana pada tahun 2017 mengalami peningkatan sebesar 2,33\%, (data olahan BPS) meskipun secara garis besar laki-laki memiliki peran yang lebih dominan dibandingkan peran wanita, namun dari hasil peningkatan peran wanita ini dapat diambil sebuah kesimpulan bahwa wanita memiliki peran yang penting dalam pembangunan ekonomi, karena kenaikan peran wanita ini memberikan tanda bahwa semakin banyak wanita yang terjun menjadi seorang wanita karir, dan peran wanita menjadi wanita karir ini tentunya akan membantu meningkatkan kondisi ekonomi rumah tangga secara khususnya dan meningkatkan kondisi ekonomi negara pada umumnya.

Wanita karir adalah berhubungan dengan pekerjaan yang menghasilkan uang, cenderung pada pemanfaatan jiwa atau karena adanya suatu aturan, maka wanita memperoleh pekerjaan, penghasilan, jabatan dan lain sabagainya Endang T. Suryadi dalam Wirakristama (2011). Menjadi seorang wanita karir adalah sebuah impian sebagian besar wanita, bukan hanya wanita yang masih lajang, namun juga wanita yang sudah berumah tangga menginginkan hal tersebut, memiliki pekerjaan di kantor, memiliki jabatan yang tinggi, dan memiliki penghasilan, karena dengan tercapainya hal tersebut akan menciptakan kepuasan tersendiri dalam diri.

Kodrat seorang wanita yang sudah berumah tangga adalah menjadi seorang istri dan seorang ibu, tentunya dengan seorang wanita menjadi seorang wanita karir dan sekaligus menjadi seorang istri dan ibu akan menimbulkan sebuah konflik peran ganda. Konflik peran ganda adalah bentuk konflik antar peran (interrole conflict) yang mana peran pekerjaan dan keluarga membutuhkan perhatian yang sama. Greenhouse \& Beutell (1985:77) dalam Idha (2013). Tuntutan dua peran untuk mendapat perhatian yang sama ini terkadang membuat seorang wanita mengalami kebingungan.

Konflik peran ganda ini seharusnya mendapatkan perhatian karena hal ini dapat mempengaruhi kinerja karyawan, selain itu juga memicu timbulnya stres kerja, Beehr dan Franz (dikutip Bambang Trumpolo, 2002:17), mendefinisikan stres kerja sebagai suatu proses yang menyebabkan orang merasa sakit, tidak nyaman atau tegang karena pekerjan, tempat kerja atau situasi kerja yang tertentu. Apabila keadaan tersebut dibiarkan berlarut dan tidak segera ditangani maka bisa saja menimbulkan sebuah pengaruh pada kemampuan karyawan dalam mengoptimalkan keahliannya dalam pekerjaan atau dengan kata lain dapat memicu timbulnya penurunan kinerja karyawan.

Menurut Nurlaili (2010) menyatakan bahwa Performance atau kinerja adalah hasil atau keluaran dari suatu proses. Luthans (2003) juga menjelaskan menggunakan pendekatan perilaku dalam manajemen, kinerja adalah kualitas atau kuantitas sesuatu yang dihasilkan atau jasa yang diberikan oleh seseorang yang melakukan pekerjaan. Dari beberapa penjelasan di atas dapat kita ambil kesimpulan bahwa kinerja karyawan dalam sebuah perusahaan sangat mempengaruhi maju atau mundurnya perusahaan, sehingga kinerja karyawan harus selalu dijaga agar stabil dan akan lebih baik apabila mengalami peningkatan.

PT. Sukorintex adalah sebuah perusahaan yang bergerak dibidang produksi, dan seperti penjabaran di atas bahwa sarung Wadimor sudah diexpor ke beberapa negara, sehingga selain menggunakan mesin dengan teknologi yang canggih, pastinya juga dengan jumlah tenaga kerja yang tidak sedikit, dimana jumlah tenaga kerja PT. Sukorintex adalah sebagai berikut:

Tabel 1. Jumlah Karyawan PT. Sukorintex Batang Bulan Oktober 2018

\begin{tabular}{|c|c|c|}
\hline No & Jenis Kelamin & Jumlah \\
\hline 1 & Laki-laki & 1.714 \\
\hline 2 & Perempuan & 1.174 \\
\hline \multicolumn{2}{|c|}{ Total } & 2.888 \\
\hline
\end{tabular}

Sumber : PT. Sukorintex Batang 
Dari tabel di atas dapat dilihat bahwa PT. Sukorintex Batang memiliki banyak karyawan wanita dimana jumlah karyawan wanita PT. Sukorintex dalam persen adalah sebesar 40,6\% yang itu artinya jumlah karyawan wanita PT. Sukorintex cukup besar dan memiliki andil yang besar pula dalam perusahaan.

Berikut ini merupakan penelitian - penelitian terdahulu yang telah dilakukan sebelumnya yang berkaitan dengan konflik peran ganda dan stress kerja terhadap kinerja karyawan wanita.

1. Pengaruh Konflik Peran Ganda Dan Stres Kerja Terhadap Kinerja Polisi Wanita Di Polresta Surakarta, penelitian ini dilakukan oleh Ririn Wedya Mayang Sari pada tahun 2016, hasil dari penelitian tersebut adalah Konflik peran ganda tidak berpengaruh signifikan terhadap kinerja karyawan hal ini dibuktikan dari Uji $\mathrm{T}$ sebesar 1,584 dengan signifikan sebesar 0,118. Sementara stres kerja berpengaruh positif dan signifikan terhadap kinerja polisi wanita Polresta Surakarta, hal ini dibuktikan dari hasil Uji T sebesar 6,694 dengan signifikan 0,00 arah yang positif.

2. Pengaruh Konflik Peran Ganda Dan Ster Kerja Terhadap Kinerja Karyawan Wanita Pada Swalayan Era Mart 5000 Di Samarinda, penelitian ini dilakukan oleh Ida Ayu Widya Ningrum pada tahun 2012. Hasil penelitian ini adalah Koefisien regresi $(\beta)$ X sebesar 0,018 memberikan arti bahwa konflik pekerjaan Keluarga (peran ganda), berpengaruh positif dan signifikan terhadap kinerja karyawan wanita swalayan Era Mart, sementara stres kerja berpengaruh positif dan signifikan terhadap kinerja karyawan, hal ini dibuktikan dengan hasil analisis regresi stres kerja 0,417 .

\section{METODE PENELITIAN \\ Populasi Penelitian}

Menurut Riduwan (2008) populasi adalah wilayah generalisasi yang terdiri atas obyek atau subjek yang menjadi kuantitas dan karakteristik tertentu yang ditetapkan oleh peneliti untuk dipelajari dan kemudian untuk ditarik kesimpulan. Berikut merupakan tabel jumlah tenaga kerja wanita PT. Sukorintex Batang Bagian Packaging.

Tabel 2. Jumlah Karyawan Wanita Menikah Divisi Packaging PT. Sukorintex Batang

\begin{tabular}{|c|l|c|}
\hline No & \multicolumn{1}{|c|}{ Bagian } & Jumlah \\
\hline 1. & Sensor & 68 \\
\hline 2. & Pemotong & 22 \\
\hline \multicolumn{2}{|c|}{ Total } & 90 \\
\hline
\end{tabular}

Sumber : Kabag Personalia PT. Sukorintex Batang

\section{Sampel Penelitian}

Sugiyono (2008) mengemukakan bahwa sampel adalah bagian dari jumlah dan karakteristik yang dimiliki oleh populasi tersebut. Menurut Arikunto (2010) mendefinisikan sampel adalah sebagian atau wakil dari populasi yang diteliti.

Menurut Arikunto jika jumlah subjeknya besar dapat diambil antara 10-15 persen atau 20-25 persen atau lebih, apabila subjeknya kurang dari 100, lebih baik diambil semua sehingga penelitiannya merupakan penelitian menggunakan metode populasi.

Dengan demikian sampel yang akan diambil dalam penelitian ini adalah 70 persen dari populasi yaitu 89,6 atau dibulatkan menjadi 90 responden. Pengambilan sampel (sampling) secara acak atau random (probabillity sampling). Dengan demikian diperoleh sampel karyawan wanita PT. Sukorintex sebagai berikut:

Tabel 3. Jumlah Tenaga Kerja Wanita Menikah PT. Sukorintex Divisi Packaging yang Menjadi Sampel

\begin{tabular}{|l|l|l|}
\hline No & \multicolumn{1}{|c|}{ Bagian } & Jumlah \\
\hline 1. & Sensor & 106 \\
\hline 2. & Pemotong & 22 \\
\hline Total & & $\mathbf{1 2 8}$ \\
\hline
\end{tabular}

Sumber: Kabag Personalia PT. Sukorintex Batang 


\section{Metode Analisis Data \\ Uji Validitas}

Uji validitas berguna untuk mengetahui apakah ada pertanyaan - pertanyaan pada kuesioner yang harus dibuang atau diganti karena dianggap tidak relevan dalam pengujian yang dihitung secara statistik (Husein umar, 2008), atau bisa dikatakan uji validitas digunakan untuk mengukur valid tidaknya suatu kuesioner. Uji statistik korelasi product moment adalah analisis untuk menguji validitas instrumen yang dicapai apabila data yang dihasilkan dari instrumen tersebut sesuai dengan data penelitian yang dimaksud.

\section{Uji Reliabilitas}

Uji reliabilitas berguna untuk menetapkan apakah instrumen dalam kuesioner dapat digunakan lebih dari satu kali paling tidak oleh responden yang sama, misal seseorang yang telah menguji kuesioner pertama hilang. Isian kuesioner pertama dan kedua haruslah sama atau dianggap sama (Husein Umar, 2008) atau dapat dikatakan uji reabilitas dilakukan untuk mengetahui apakah instrumen atau alat ukur yang dipergunakan memiliki konsistensi yang baik atau tidak. Pengujian reabilitas pada penelitian ini menggunakan cronbach alpha.

\section{Uji Asumsi Klasik}

Uji asumsi klasik digunakan sebagai persyaratan sebelum melakukan analisis regresi linier, analisis regresi linier mempergunakan asumsi bebas dari uji normalitas, uji multikolonieritas, dan uji heteroskedastisitas.

\section{Uji Normalitas}

Untuk menghindari terjadinya bias, data yang digunakan harus berdistribusi normal. Uji normalitas bertujuan untuk menguji apakah dalam model regresi variabel - variabel independen mempunyai distribusi normal atau tidak. Hal ini dikarenakan bahwa untuk penelitian yang menggunakan regresi linier berganda perlu diuji dengan uji normalitas data. Model regresi yang baik adalah memiliki distribusi normal (Ghozali, 2011). Salah satu cara untuk melihat normalitas adalah dengan melihat histogram yang membandingkan antara satu observasi dengan distribusi normal. Metode yang handal untuk melihat analisis grafik adalah dengan melihat normal probability plot yang membandingkan distribusi kumulatif dari data sesungguhnya dengan distribusi kumulatif dari distribusi normal.

\section{Uji Multikolonieritas}

Uji multikolonieritas bertujuan untuk menguji apakah model regresi ditemukan adanya korelasi antar variabel bebas (Husein Umar, 2008). Multikolonieritas dapat dilihat dari nilai toleransinya dan lawannya atau variance inflantion factor (VIF). Jika VIF kurang dari 10 dan nilai toleransi lebih dari 0,1 maka regresi bebas dari multikolonieritas.

\section{Uji Heteroskedastitas}

Uji heteroskedastisitas dilakukan untuk mengetahui apakah dalam sebuah model regresi terjadi ketidaksamaan varian dari residual suatu pengamatan ke pengamatan lain (husein Umar, 2008). Pengujian terhadap heteroskedastisitas dapat dilakukan melalui pengamatan terhadap pola scatter plot membentuk pola tertentu, maka model regresi memiliki gejala heteroskedastisitas.

Munculnya sebuah gejala heteroskedastisitas menunjukkan bahwa penaksir dalam model regresi tidak efisien dalam sampel besar maupun kecil. Jika tidak ada pola yang jelas dan titik titik menyebar diatas dan bawah angka nol pada sumbu Y, maka dapat disimpulkan bebas heteroskedastisitas.

\section{Analisis Regresi Linier}

Analisis data yang digunakan dalam penelitian ini adalah Analisis Linier. Analisis Regresi Linier dikembangkan untuk mengestimasi pengaruh antar variabel dependen terhadap variabel independen (Gudjarati, 2003). 


\section{Uji t (Regresi Parsial)}

Uji parsial atau uji t digunakan untuk menguji pengaruh variabel bebas secara parsial terhadap variabel terikat (Gudjrati, 2003). Dalam penelitian ini menggunakan SPSS dengan tingkat signifikan 5\% (0,05). Adapun ketentuannya adalah sebagai berikut:

a. Jika $\mathrm{t}$ hitung $\leq \mathrm{t}$ tabel pada tingkat kepercayaan $5 \%$ atau nilai probabilitas signifikan (sig). Lebih besar dari 0,05 maka Ho diterima.

b. Jika $\mathrm{t}$ hitung $\geq \mathrm{t}$ tabel pada tingkat kepercayaan $5 \%$ atau nilai probabilitas signifikan (sig). Lebih kecil dari 0,05 maka Ho ditolak dan menerima Ha.

\section{Uji F (Regresi Simultan)}

Uji statistik F digunakan untuk menguji apakah model regresi yang digunakan cocok atau tidak (Ghozali, 2012). Dasar dalam pengambilan keputusannya adalah:

a. Bila F-hitung < F-tabel, maka model regresi tidak cocok (hipotesis ditolak).

b. Bila F-hitung > F-tabel, maka model regresi cocok (hipotesis diterima).

\section{Koefisien Determinasi $\left(\mathbf{R}^{2}\right)$}

Koefisien determinasi $\left(\mathrm{R}^{2}\right)$ pada dasarnya untuk mengukur seberapa jauh kemampuan model dalam menerangkan variasi variabel dependen. Nilai koefisien determinasi adalah antara nol dan satu. Nilai $\left(\mathrm{R}^{2}\right)$ yang kecil berarti kemampuan variabel - variabel independen dalam menjelaskan variasi variabel dependen amat terbatas. Nilai yang mendekati satu berarti variabel - variabel independen memberikan hampir semua informasi yang dibutuhkan untuk memprediksi variasi variabel dependen (Ghozali, 2011).

\section{HASIL DAN PEMBAHASAN \\ Uji Validitas}

Dari pengujian yang dilakukan menunjukan bahwa korelasi antara masing -masing indikator terhadap skor dari tiap variabel menunjukan hasil yang signifikan dan menunjukan bahwa $r$ hitung > $r$ tabel. Sehingga dapat ditarik kesimpulan bahwa item pernyataan dinyatakan valid.

\section{Uji Reliabilitas}

Tabel 4. Hasil Pengujian Reliabilitas

\begin{tabular}{|c|c|c|}
\hline Variabel & Alpha Cronbach & Keterangan \\
\hline Konflik peran ganda & 0.734 & Reliabel \\
\hline Stres kerja & 0.661 & Reliabel \\
\hline Kinerja karyawan & 0.678 & Reliabel \\
\hline
\end{tabular}

Sumber : Data primer yang diolah, 2019

Hasil pengujian reliabilitas di atas menunjukan bahwa semua variabel mempunyai koefisien alpha yang cukup besar yaitu diatas 0.60 sehingga dapat dikatakan semua konsep pengukur masing-masing variabel dari kuesioner adalah reliabel. 


\section{Uji Asumsi Klasik \\ Uji Normalitas}

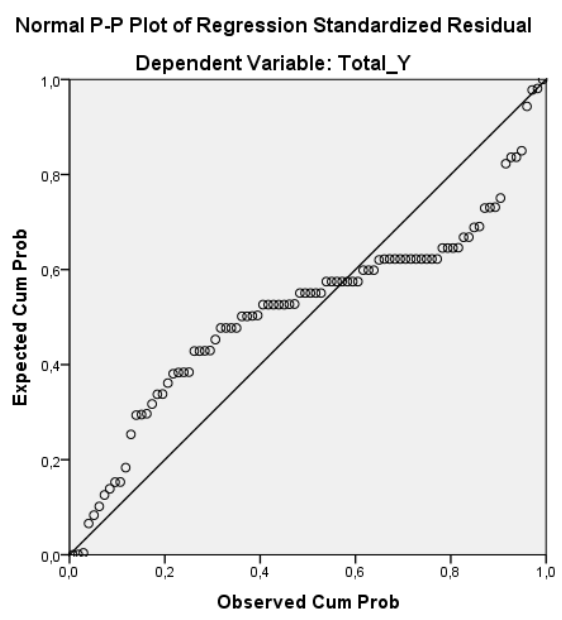

Gambar 1. Hasil Pengujian Normalitas

Sumber : Data Primer yang diolah SPSS 22, 2019

Dari gambar tersebut dapat dilihat bahwa hasil pengujian data adalah terdistribusi secara normal, karena data menyebar di sekitar garis diagonal dan mengikuti arah garis diagonal sehingga dapat dinyatakan bahwa model regresi memenuhi asumsi normalitas.

\section{Uji Multikolonieritas}

Tabel 5. Hasil Uji Multikolonieritas

\begin{tabular}{|l|l|c|c|}
\hline No & \multicolumn{1}{|c|}{ Variabel Bebas } & Nilai Tolerance & Nilai VIF (\%) \\
\hline 1. & Konflik Peran Ganda & 0,406 & 2,460 \\
\hline 2. & Stres Kerja & 0,406 & 2,460 \\
\hline
\end{tabular}

Sumber: Data primer yang diolah SPSS 22, 2019

Dari tabel di atas dapat dilihat bahwa nilai VIF semua variabel bebas dalam penelitian ini lebih kecil dari 10 sedangkan nilai toleransi semua variabel bebas lebih besar dari 10\%. Dengan demikian dapat disimpulkan bahwa tidak terdapat gejala multikolonieritas antara variabel bebas dalam model regresi.

\section{Uji Heteroskedastisitas}

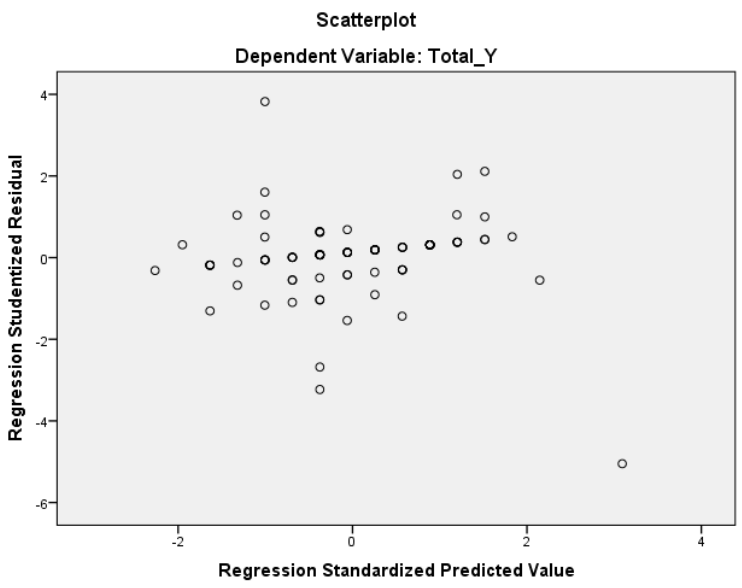

Gambar 2. Hasil Pengujian Heteroskedastisitas

Sumber : Data primer yang diolah SPSS 22, 2019 
Dari gambar di atas dapat dilihat bahwa titik-titik menyebar secara acak dan tidak membentuk pola tertentu yang jelas, serta menyebar dengan baik di atas maupun di bawah angka nol pada sumbu Y. Sehingga dapat diambil kesimpulan bahwa variabel tidak mengalami heteroskedastisitas atau data bersifat homogen.

\section{Analisis Regresi Linier}

Tabel 6. Hasil Uji Analisis Regresi

\begin{tabular}{|l|r|r|r|r|r|r|r|}
\hline \multirow{2}{*}{ Model } & \multicolumn{1}{|c|}{$\begin{array}{c}\text { Unstandardized } \\
\text { Coefficients }\end{array}$} & $\begin{array}{c}\text { Standardized } \\
\text { Coefficients }\end{array}$ & & & \multicolumn{2}{|c|}{$\begin{array}{c}\text { Collinearity } \\
\text { Statistics }\end{array}$} \\
\cline { 2 - 4 } & \multicolumn{1}{|c|}{ B } & Std. Error & Beta & T & Sig. & Tolerance & VIF \\
\hline (Constant) & 31,919 & 1,726 & & 18,498 &, 000 & & \\
Total_X1 &, 889 &, 096 &, 842 & 9,259 &, 000 &, 406 & 2,460 \\
Total_X2 &,- 001 &, 087 &,- 001 &,- 015 &, 988 &, 406 & 2,460 \\
\hline
\end{tabular}

\section{Uji Hipotesis}

Uji t (Parsial)

Tabel 7. Hasil Uji t

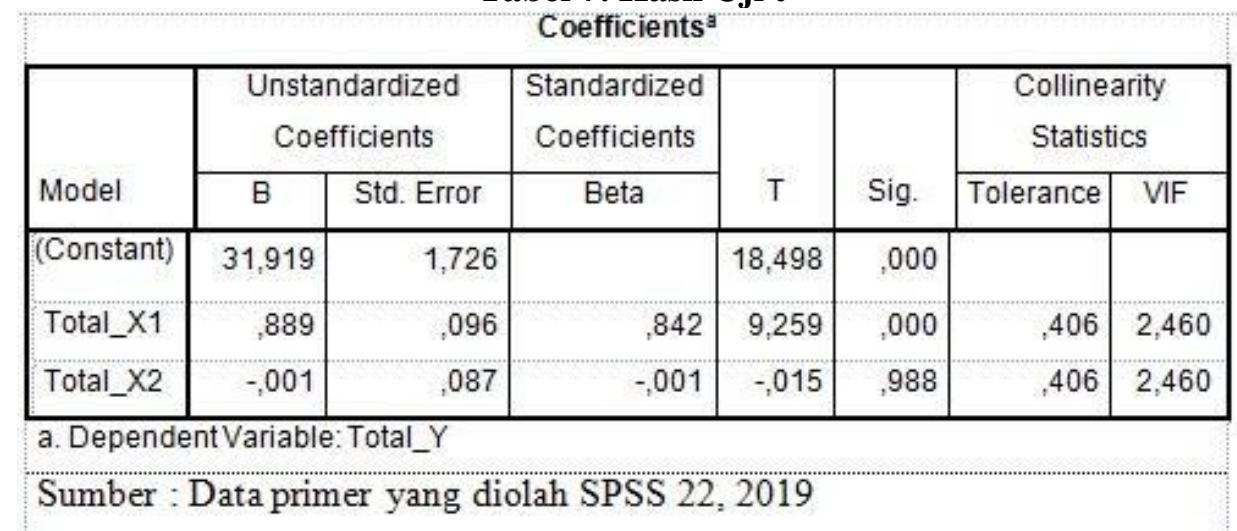

Uji parsial ini mengambil kesimpulan dengan pertimbangan bahwa jika nilai $\mathrm{t}$ hitung $>\mathrm{t}$ tabel maka H0 ditolak dan Ha diterima atau jika $\mathrm{p}<0,05$ maka $\mathrm{H} 0$ ditolak dan Ha diterima. Berdasarkan hasil uji parsial di atas maka dapat disimpulkan bahwa :

1. Variabel konflik peran ganda diperoleh t hitung 9,259 dengan probabilitas signifikan 0,000 . Berdasarkan hasil tersebut $t$ hitung 9,259 $>\mathrm{t}$ tabel 1,98 atau $\mathrm{p}<0,05(0,000<0,05)$, maka H0 ditolak dan Ha diterima, dapat disimpulkan bahwa konflik peran ganda berpengaruh terhadap kinerja karyawan wanita menikah PT. Sukorintex

2. Variabel stres kerja memperoleh $\mathrm{t}$ hitung $(-0,015)$ dengan probabilitas signifikan 0,988 . Berdasarkan hasil tersebut $t$ hitung $(-0,015)<\mathrm{t}$ tabel 1,98 atau $\mathrm{p}>0,05(0,988>0,05)$, maka $\mathrm{H} 0$ diterima dan Ha ditolak, dapat disimpulkan bahwa stres kerja tidak berpengaruh terhadap kinerja karyawan wanita menikah PT. Sukorintex. 


\section{Uji F (Simultan)}

Tabel 8. Hasil Uji F

\begin{tabular}{|c|c|c|c|c|c|c|}
\hline \multicolumn{7}{|c|}{ ANOVA $^{3}$} \\
\hline \multicolumn{2}{|c|}{ Model } & $\begin{array}{l}\text { Sum of } \\
\text { Squares }\end{array}$ & Df & Mean Square & $\mathrm{F}$ & Sig. \\
\hline \multirow[t]{3}{*}{1} & Regression & 705,789 & 2 & 352,894 & 105,211 &, $000^{\circ}$ \\
\hline & Residual & 291,811 & 87 & 3,354 & & \\
\hline & Total & 997,600 & 89 & & & \\
\hline
\end{tabular}

Sumber :Data primer yang diolah SPSS 22, 2019

Berdasarkan hasil uji $\mathrm{F}$ (regresi simultan) pada tabel diatas diketahui bahwa $\mathrm{F}$ hitung $>\mathrm{F}$ tabel $(105,211>3,10)$, maka H0 ditolak dan Ha diterima dengan tingkat probabilitas signifikan 0,000 . Berdasarkan hasil tersebut maka $\mathrm{p}<0,05(0,000<0.05)$. Sehingga dapat disimpulkan bahwa secara simultan atau bersama-sama konflik peran ganda dan stres kerja berpengaruh dan signifikan terhadap kinerja karyawan wanita menikah PT. Sukorintex.

\section{Uji Koefisien Determinasi $\left(\mathbf{R}^{2}\right)$}

Tabel 9. Hasil Uji Determinasi

\begin{tabular}{|l|r|r|r|r|}
\hline \multicolumn{1}{|c|}{ Model Summary $^{\mathrm{b}}$} \\
\hline Model & $\mathrm{R}$ & $\mathrm{R}$ Square & Adjusted R Square & $\begin{array}{c}\text { Std. Error of the } \\
\text { Estimate }\end{array}$ \\
\hline 1 &, $841^{\mathrm{a}}$ &, 707 &, 701 & 1,831 \\
\hline a. Predictors: (Constant), Total_X2, Total_X1 \\
b. DependentVariable:Total_Y
\end{tabular}

Sumber : Data primer olahan SPSS 22, 2019

Berdasarkan hasil uji $\mathrm{R}$ di atas diketahui bahwa nilai $\mathrm{r}$ sebesar 0,841 yang artinya variabel dependen dengan variabel independen memiliki hubungan yang tinggi. Nilai $\mathrm{R}$ square sebesar 0,707 artinya variabel independen memberikan pengaruh terhadap variabel dependen sebesar $70,7 \%$ sedangkan $29,3 \%$ lainnya dipengaruhi oleh model diluar variabel yang dibahas dalam penelitian ini.

\section{PEMBAHASAN}

\section{Pengaruh Konflik Peran Ganda Terhadap Kinerja Karyawan Wanita Menikah}

Berdasarkan pengujian hipotesis (H1) telah membuktikan bahwa terdapat pengaruh antara konflik peran ganda terhadap kinerja karyawan wanita menikah. Hasil dari pengujian variabel konflik peran ganda diperoleh t hitung 9,259 dengan probabilitas signifikan 0,000. Berdasarkan hasil tersebut $\mathrm{t}$ hitung 9,259 $>\mathrm{t}$ tabel 1,98 atau $\mathrm{p}<0,05(0,000<0,05)$, maka $\mathrm{H} 0$ ditolak dan Ha diterima, dapat disimpulkan bahwa konflik peran ganda berpengaruh terhadap kinerja karyawan wanita menikah PT. Sukorintex. Hal tersebut mendukung penelitian sebelumnya yang dilakukan oleh Ida Ayu Widyaningrum (2012) yang menyatakan bahwa konflik peran ganda berpengaruh positif dan signifikan terhadap kinerja karyawan wanita.

Dari hasil penelitian pada variabel konflik peran ganda pada PT. Sukorintex Batang yang memiliki nilai index paling kuat adalah time based conflict. Kondisi ini dapat dilihat dari jawaban 
responden yang diterima pada indikator time based conflict yaitu adalah konflik yang terjadi karena waktu yang digunakan untuk memenuhi satu peran tidak dapat digunakan untuk memenuhi peran lainnya, dimana dalam penelitian ini justru sebaliknya dimana seseorang yang memiliki tekanan berdasar waktu justru berdampak positif pada kinerja mereka, dimana justru semakin baik dalam bekerja dan sesegera mungkin untuk dapat kembali ke rumah guna memanfaatkan waktu yang tersedia untuk urusan lainnya.

\section{Pengaruh Stres Kerja Terhadap Kinerja Karyawan Wanita Menikah}

Hasil uji hipotesis (H2) telah membuktikan bahwa tidak terdapat pengaruh antara stres kerja terhadap kinerja karyawan wanita menikah. Berdasarkan hasil pengujian spss versi 22 menunjukan hasil sebagai berikut: variabel stres kerja memperoleh $\mathrm{t}$ hitung $(-0,015)$ dengan probabilitas signifikan 0,988. Berdasarkan hasil tersebut t hitung $(-0,015)<\mathrm{t}$ tabel 1,98 atau $\mathrm{p}>0,05(0,988>$ 0,05), maka H0 diterima dan Ha ditolak, dapat disimpulkan bahwa stres kerja tidak berpengaruh terhadap kinerja karyawan wanita menikat PT. Sukorintex. Hal ini mendukung penelitian Sry Rosita (2012) yang menyatakan bahwa stres kerja tidak berpengaruh terhadap kinerja dosen wanita fakultas ekonomi Jambi.

Dari hasil index penelitian yang paling rendah adalah sikap pemimpin, dimana sikap pemimpin adalah suatu sikap pimpinan yang diukur dari persepsi responden mengenai sikap pemimpin yang kurang adil atau kurang mampu mengerti karyawan. Keadilan dalam proses pemberian tugas, kemampuan seorang pemimpin untuk mampu memberikan motivasi bagi karyawan akan memberikan efek yang bagus bagi kinerja karyawan, namun jika seorang cenderung kurang mampu memberikan keadilan dan kurang mampu memotivasi karyawan maka akan memberikan efek sebaliknya pula.

\section{Pengaruh Konflik Peran Ganda dan Stres Kerja Terhadap Kinerja Karyawan Wanita Menikah}

Hasil uji hipotesis (H3) menunjukan bahwa terdapat pengaruh yang positif dan signifikan antara konflik peran ganda dan stres kerja terhadap kinerja karyawan wanita. Berdasarkan hasil uji $\mathrm{F}$ (regresi simultan) pada penelitian ini, diketahui bahwa $\mathrm{F}$ hitung > F tabel $(105,211>3,10)$, maka $\mathrm{H} 0$ ditolak dan Ha diterima dengan tingkat probabilitas signifikan 0,000. Berdasarkan hasil tersebut maka $\mathrm{p}<0,05(0,000<0.05)$. Sehingga dapat disimpulkan bahwa secara simultan atau bersamasama konflik peran ganda dan stres kerja berpengaruh positif dan signifikan terhadap kinerja karyawan wanita menikah PT. Sukorintex Batang.

Berdasarkan uji koefisien determinasi $\left(\mathrm{R}^{2}\right)$ variabel konflik peran ganda dan stres kerja terhadap kinerja karyawan diperoleh nilai $\mathrm{R}$ sebesar 0,841 yang artinya variabel dependen dengan variabel independen memiliki hubungan yang tinggi. Nilai $R$ square sebesar 0,707 artinya variabel indepennden memberikan pengaruh terhadap variabel dependen sebesar 70,7\% sedangkan $29,3 \%$ lainnya dipengaruhi oleh model diluar variabel yang lain misalnya kompesasi, disiplin kerja dan lain sebagainya.

\section{KESIMPULAN}

Dari data primer dengan cara penyebaran kuesioner maka dilakukan pengujian validitas yang digunakan untuk mengukur valid atau tidaknya suatu pernyataan dalam kuesioner, dan dilakukannya pengujian reliabilitas untuk mengetahui bahwa jawaban seluruh pernyataan dalam setiap variabel dapat dinyatakan valid dan konsisten.

Dalam uji asumsi klasik seperti uji multikolonieritas, uji heteroskedastisitas dan uji normalitas menunjukan bahwa dalam model regresi tidak ditemukan adanya korelasi antara variabel bebas dan tidak terjadi heteroskedastisitas serta memiliki distribusi normal. Dari pembahasan yang telah diuraikan, maka dapat ditarik kesimpulan sebagai berikut:

1. Hasil pengujian hipotesis (H1) yang dilakukan membuktikan adanya pengaruh positif dan signifikan antara konflik peran ganda dan stres kerja terhadap kinerja karyawan wanita menikah. Dilihat dari hasil perhitungan diperoleh nilai t hitung 9,259 dengan probabilitas signifikan 0,000. Berdasarkan hasil tersebut $t$ hitung 9,259 $>\mathrm{t}$ tabel 1,98 atau $\mathrm{p}<0,05(0,000$ $<0,05)$, maka H0 ditolak dan Ha diterima, dapat disimpulkan bahwa konflik peran ganda 
berpengaruh positif dan signifikan terhadap kinerja karyawan wanita menikah PT. Sukorintex Batang.

2. Hasil pengujian hipotesis (H2) yang dilakukan membuktikan bahwa tidak ada pengaruh antara stres kerja terhadap kinerja karyawan wanita menikah. Dari hasil perhitungan diperoleh hasil sebagai berikut $t$ hitung $(-0,015)$ dengan probabilitas signifikan 0,988 . Berdasarkan hasil tersebut t hitung $(-0,015)<\mathrm{t}$ tabel 1,98 atau $\mathrm{p}>0,05(0,988>0,05)$, maka $\mathrm{H} 0$ diterima dan Ha ditolak, dapat disimpulkan bahwa stres kerja tidak berpengaruh terhadap kinerja karyawan wanita menikah PT. Sukorintex Batang.

3. Hasil pengujian hipotesis (H3) membuktikan bahwa secara simultan konflik peran ganda dan stres kerja berpengaruh positif dan signifikan terhadap kinerja karyawan wanita menikah. Dari hasil perhitungan yang dilakukan diperoleh nilai sebagai berikut $\mathrm{F}$ hitung > F tabel $(105,211$ $>3,10)$, maka H0 ditolak dan Ha diterima dengan tingkat probabilitas signifikan 0,000. Berdasarkan hasil tersebut maka $\mathrm{p}<0,05(0,000<0.05)$. Sehingga dapat disimpulkan bahwa secara simultan atau bersama-sama konflik peran ganda dan stres kerja berpengaruh positif dan signifikan terhadap kinerja karyawan wanita menikah PT. Sukorintex Batang.

\section{SARAN}

Hasil penelitian ini menunjukkan bahwa konflik peran ganda dan stres kerja akan berpengaruh terhadap kinerja karyawan. Hasil tersebut memberikan beberapa implikasi manajerial yaitu sebagai berikut:

1. Berdasarkan penelitian diketahui bahwa pada variabel Konflik peran ganda pada indikator behavior based conflict memiliki index paling rendah oleh karena itu karyawan PT. Sukorintex Batang diharapkan lebih mampu menyeimbangkan atau menempatkan suatu sikap pada peran yang sedang dijalaninya yaitu pada saat menjadi seorang karyawan dan pada saat menjadi seorang ibu serta istri di dalam keluarga. Langkah-langkah ini diharapkan dapat mencegah terjadinya konflik peran ganda dan dapat meningkatkan kinerja karyawan wanita menikah PT. Sukorintex Batang.

2. Berdasarkan hasil penelitian diketahui bahwa stres kerja pada indikator waktu kerja memiliki index paling tinggi dimana karyawan merasa sering bekerja lebih dari 8 jam dalam sehari dan merasa dikejar waktu dalam menyelesaikan targetnya, oleh karena itu perusahaan hendaknya lebih memperhatikan waktu kerja karyawan dengan menambah jumlah karyawan atau lain sebagainya. Langkah ini diharapkan akan mengurangi stres kerja yang dirasakan oleh karyawan wanita menikah pada PT. Sukorintex Batang.

\section{PENELITIAN LANJUTAN}

Berdasarkan uji koefisien determinasi $\left(\mathrm{R}^{2}\right)$ variabel konflik peran ganda dan stres kerja terhadap kinerja karyawan diperoleh nilai $\mathrm{R}$ sebesar 0,841 yang artinya variabel dependen dengan variabel independen memiliki hubungan yang tinggi. Nilai $R$ square sebesar 0,707 artinya variabel independen memberikan pengaruh terhadap variabel dependen sebesar 70,7\% sedangkan 29,3\% lainnya dipengaruhi oleh model diluar variabel yang lain oleh karena itu perlu diadakannya penelitian lanjutan diluar varibel konflik peran ganda dan stres kerja misalnya pelatihan, disiplin kerja dan lain sebagainya.

Pelatihan merupakan salah satu faktor yang penting dalam kinerja karyawan, pelatihan merupakan salah satu usaha dalam meningkatkan kinerja karyawan. Karyawan, baik yang baru ataupun yang sudah bekerja perlu mengikuti pelatihan karena adanya tuntutan pekerjaan yang dapat berubah akibat perubahan lingkungan kerja, strategi, dan lain sebagainya. (Dessler, 2009).

Kinerja karyawan memiliki kaitan yang erat dengan disiplin kerja, hal ini dikarenakan disiplin adalah faktor operatif keenam dari Sumber Daya Manusia (Hasibuan, 2001). Semakin baik disiplin kerja karyawan maka kinerja karyawan akan semakin baik, sebaliknya jika disiplin kerja karyawan buruk maka sulit untuk seorang karyawan mencapai hasil kinerja secara optimal.

\section{KETERBATAS PENELITIAN}

1. Faktor-faktor yang mempengaruhi kinerja dalam penelitian ini hanya menggunakan dua variabel yaitu variabel konflik peran ganda dan stres kerja, sementara kinerja karyawan memiliki banyak faktor lain yang dapat mempengaruhinya. 
2. Adanya keterbatasan penelitian menggunakan kuesioner sebagai alat pengumpul data dan tidak disertai dengan metode pengumpulan data yang lain yang dapat menunjang metode penelitian. Dari 90 data kuesioner yang disebarkan kuesioner dinyatakan lengkap dan layak untuk diteliti dan diuji lebih lanjut.

\section{DAFTAR PUSTAKA}

Alih, Y. N. 2018. "Pengaruh Konflik Peran Ganda dan Stres Kerja Terhadap Kinerja Perawat Wanita Berperan ganda (Studi pada RSUD Hj. Anna Lasmanah Banjarnegara)'. Surakarta: Universitas Muhammadiyah Surakarta.

Anoraga, Pandji. 1992. Psikologis Kerja. Jakarta: Rineka Cipta.

Anoraga, Panji. 1998. Psikologi Kerja. Jakarta Rineka Cipta.

Anoraga, Pandji. 2001. Psikologi Kerja. Jakarta: Rineka Cipta.

Arikunto, S. 2010. Prosedur Penelitian: Suatu Pendekatan Praktis (Edisi Revisi). Jakarta: Rineka Cipta.

Brahmasari, Ida Ayu dan Agus Suprayetno. 2008. Pengaruh Motivasi Kerja, Kepemimpinan dan Budaya Organisasi Terhadap Kepuasan Kerja Karyawan Serta Dampak Kinerja Perusahaan ( Studi Kasus Pada PT. Pei Hei International Wiratama Indonesia. Jurnal Manajemen dan Kewirausahaan. Vol. 10

Dedy, S. 2016. "Pengaruh Work Conflict, Stres Kerja dan Kepuasan Kerja Terhadap Kinerja Karyawan”. Yogyakarta: Universitas Muhammadiyah Yogyakarta.

Dwi Burhanuddin, Trisna. Dkk. 2018. "Pengaruh Konflik Peran Ganda Terhadap Kinerja Melalui Stres Kerja”. Makassar: STIE Bongaya Makassar.

Elvina, Triana. V. 2017. "Pengaruh Stres dan Konflik Pekerjaan - keluarga

(Work Family Conflict) Terhadap Kinerja Karyawan PT. Lautan Berlian Utama Motor Cabang Waylunik Bandarlampung". Universitas Lampung.

Frone, M. R. 2000. Work - Family Conflict and Employee Psychiatric Disorder: The National Comorbidity Survey: Jurnal Of Applied Psychology Vol. 85 No. 6.

Ghozali, Imam. 2011. Aplikasi Analisis Multi Variate Dengan Program IBM SPSS 19 (Edisi 5). Semarang: Badan Penerbit Undip.

Gibson, Ivancevich dan Donelly. 1996. Organisasi. Jilid kesatu. Jakarta: Binarupa Aksara.

Greenhouse, J. H dan Buetell, N. J. 1985. Sources Of Conflict Betwen Work and Family Role, Dalam Academy Of Management Review, Vol. 10. No.1. 76-88.

Gudjrati, Damodar. 2003. Ekonometri Dasar. Terjemahan: Sumarno Zain. Jakarta: Erlangga.

Handoko, T. Hani. 2008. Manajemen Personalian dan Sumber Daya Manusia. Yogyakarta: BPFE.

Hasibuan, SP. Melayu. 2014. Manajemen Sumber Daya Manusia. Edisi Revisi. Jakarta: Bumi Aksara.

Irwan, Muhammad. 2017. "Pengaruh Stres dan Konflik Kerja Terhadap Kinerja Karyawan PT. Kalla Kakao Industri Di Kota Makassar”. Makassar: Universitas Islam Negeri Alauddin Makassar.

Irwanto, 1998. Psikologi Umum. Jakarta: PT. Gramedia.

Luthans. F. 2005. Organizational Behavior. New York: Mc. Graw - Hill.

Mathis dan Jackson. 2009. Manajemen Sumber Daya Manusia (Edisi 10). Jakarta: Salemba Empat.

Mankunegara, Anwar Prabu. 2009. Manajemen Sumber Daya Manusia. Bandung: PT. Remaja Rosdakarya.

Mangkuprawira, S. Tb. 2011. Manajemen Sumber Daya Manusia Strategik. Bogor : Ghalia Indonesia.

Nurlaili. 2010. Manajemen Sumber Daya Manusia I. Ternate: Penerbit LepKhair.

Riduwan. 2008. Dasar - Dasar Statistika. Bandung: Alfabeta.

Ririn, W.P.M.S. 2015. "Pengaruh Konflik Peran Ganda dan Stres Kerja Terhadap Kinerja Polisi Wanita Di Polres Surakarta”. Surakarta: Universitas Muhammadiyah Surakarta.

Rizzo, J., R. House and S. Litzman.1970. Role Conflict and Ambiguity In Complex Organization. Administrative Sciance Quarturly.

Robbins, S. 2003. Perilaku Organisasi. Jakarta: PT. Indeks Kelompok Gramedia. 
Robbins, S. 2006. Perilaku Organisasi. Jakarta: PT. Indeks Kelompok Gramedia.

Sadli, S. 2001. Faktor Pendukung dan Penghambat Terhadap Pengembangan Jati Diri Perempuan. Di dalam Mudzhar dkk. 2001. Wanita dalam Masyarakat Indonesia. Yogyakarta: Sunan Kalijaga Perss.

Smet, B. 1994. Psikologi Kesehatan. Terjemahan: Agus Susanto. Jakarta: PT. Grasindo.

Sry, Rosita. 2012. "Pengaruh Konflik Peran Ganda dan Stres Kerja Terhadap Kinerja Dosen Wanita Fakultas Ekonomi Universitas Jambi”. Jurna Manajemen Bisnis.Jambi: Universitas Negeri Jambi.

Suci. Larasati. M, dkk. 2016. "Pengaruh Konflik Peran Ganda (Work Family Conflict) dan Stres Kerja Terhadap Kinerja Karyawan Wanita di PT. POS Indonesia (Persero) Bandung pada Divisi Sub Direktorat SDM”. Bandung: Universitas Islam Bandung.

Sugiono. 2013. Statistika Untuk Penelitian. Bandung: Alfabeta.

Trumpolo, Bambang. 2002. Warta Kesehatan Kerja Media Komunikasi Kesehatan Kerja Edisi 2.

Umar, Husein. 2008. Riset Sumber Daya Manusia Dalam Organisasi. Jakarta: Gramedia Putaka Grup.

Vandi, N. W. 2014. "Hubungan Antara Dukungan Sosial Dengan Konflik Peran Ganda Pada Polisi Wanita Di Polres Banyumas". Purwokerto: Universitas Muhammaduyah Purwokerto.

Widyaningrum, Ida Ayu. 2013. "Pengaruh Konflik Peran Ganda dan Stres Kerja Terhadapp Kinerja Karyawan Wanita Pada Swalayan Era Mart 5000 Di Samarinda. Samarinda: Universitas Mulawarman.

Winardi. 1996. Perilaku Konsumen. Bandung.

Wirakristama, R.C. 2011. "Analisis Konflik Peran Ganda (Work-Famili Conflict) Terhadap Kinerja Karyawan Wanita Pada PT. Nyonya Meneer Semarang Denan Stres Kerja Sebagai Variabel Intervening". 